\title{
IL18R1 wt Allele
}

National Cancer Institute

\section{Source}

National Cancer Institute. IL18R1 wt Allele. NCI Thesaurus. Code C124083.

Human IL18R1 wild-type allele is located in the vicinity of $2 \mathrm{q} 12$ and is approximately $87 \mathrm{~kb}$ in length. This allele, which encodes interleukin-18 receptor 1 protein, plays a role in interleukin-18 binding and signal transduction. 